Historia | roč. 72 | 2018 | čís. 1-2 | s. 81-83

\title{
Natálie Venclová, NĚMČICE AND STARÉ HRADISKO. Iron Age glass and glass-working in Central Europe, Praha 2016.
}

\section{Viktoria Čist’akova}

Sídliště Němčice a oppidum Staré Hradisko patř́i bezpochyby k lokalitám s nadregionálním významem, a to jak v kontextu výrobní, tak i obchodní činnosti. Publikace Němčice and Staré Hradisko. Iron Age glass and glass-working in Central Europe se zaměřila na početnou nálezovou složku z těchto dvou lokalit - na skleněné nálezy z doby laténské. Studium skla z doby laténské má dlouholetou tradici, ${ }^{1}$ ostatně i pozdější studie výrazně přispěly k vytvoření chronologicky citlivější typologie skleněných výrobků. ${ }^{2}$ Vhodné je zmínit i novější práce zaměřené na studium souborů laténského skla (LT B2 - LT C1) pocházejícího z rovinných neopevněných sídlišt'. Zmiňme kupř́ikladu lokality Roseldorf a Etzersdorf v Dolním Rakousku, předoppidální fázi sídliště Manching v Bavorsku, lokalitu Nowa Cerekwia z Horního Slezska atd. ${ }^{3}$

Sídliště Němčice nad Hanou patří mezi nejvýznamnější lokality svého druhu v Evropě. I přes to, že na lokalitě nebyl doposud proveden terénní výzkum, poskytla povrchová prospekce nečekaně bohatý soubor skládající se z několika tisíc kovových, skleněných a jiných nálezů. Sbírce artefaktů dominuje bohatý soubor laténských mincí o počtu 1176 kusů (odhadem původně až 10000 mincí) datovaných do LT B2/ C1 až LT C1-C2. Systematická povrchová prospekce, která v letech 2002 až 2006 probíhala pod vedení M. Čižmáře (Ústav archeologické památkové péče Brno), přinesla 636 skleněných artefaktů, které jsou doplněny o dalších 1387 skleněných předmětů, nalezených během neodborných sběrů.

Vhodné je zmínit, že výsledky povrchové prospekce, která pokryla plochu 30 ha, byly doplněny o geofyzikální průzkum lokality (kapitola 1.2). Nedestruktivní geofyzikální průzkum v letech 2002-2012 pokryl plochu 44,21 ha, ${ }^{4} \mathrm{kde}$ byly identifikovány stovky reliktů sídelních objektů (jámy

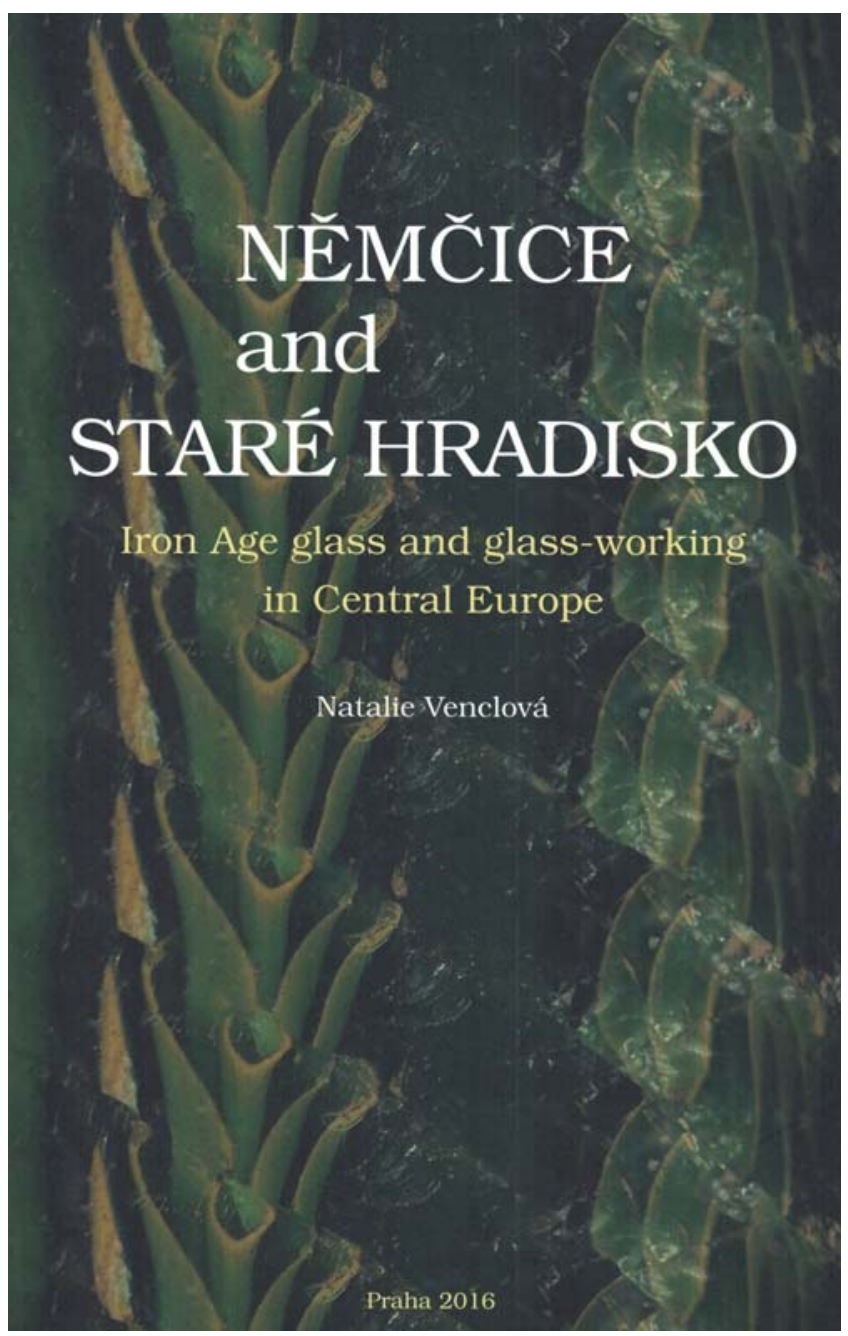

\footnotetext{
${ }^{1}$ Např. Joseph DÉCHELETTE 1914, Manuel d'archéologie préhistorique celtique et gallo-romaine 2. - Troisième partie Archéologie celtique et protohistorique. - Second âge du fer ou époque de la Tène. Material description: 1 vol., 2014, s. 911-1693; Josef SKUTIL, Skleněné náramky ze Starého Hradiska. Ročenka musea v Prostějově, 1939, roč. 16, s. 110-119; Thea Elisabeth HAEVERNICK, Die Glasarmringe und Ringperlen der Mittel- und Spätlatènezeit auf dem europäischen Festland, Bonn 1960.

${ }^{2}$ Gertrúda BŘEZINOVÁ, Glass rings decoration of the La Tène period from Slovakia, Archaeologia Polona, 2007, č. 45, s. 35-40; Rupert GEBHARD, Der Glasschmuck aus dem Oppidum von Manching, Die Ausgrabungen in Manching, Band 11, Stuttgart 1989; Maciej KARWOWSKI, Keltische Glassfunde im Polnischen Gebiet, Przegląd Archeologiczny, 1997, roč. 45, s. 33-71; Natálie VENCLOVÁ, Prehistoric glass in Bohemia, Praha 1990.

R. GEBHARD, Der Glasschmuck aus dem Oppidum von Manching, Stuttgart 1989; Maciej KARWOWSKI, Latène zeitlicher Glasringschmuck aus Ostösterreich, Mitteilungen der Prähistorischen Kommission, 2004; Marcin RUDNICKI, Nowa Cerekwia - the Middle La Tène center of power north of the Carpathians, in: Jana ČIŽMÁŘOVÁ - Natálie VENCLOVÁ - Gertrúda BŘEZINOVÁ (eds.), Moravské křižovatky. Střední Podunají mezi pravěkem a historií, Brno 2014, s. 421-437.
} 
a domy). Zajímavým zjištěním byla identifikace polohy objektů poškozených vysokým žárem, které s jistou pravděpodobností mohou být ztotožněny s výrobním zázemím sídliště: pece a/nebo místo s výrobním odpadem. Při povrchové prospekci byl kromě hotových výrobků identifikován i tzv. sklářský výrobní odpad. Kombinace prostorové distribuce skleněných výrobků, sklářského odpadu a identifikace pyrotechnologických objekti̊ potvrzuje intenzivní výrobní činnost (včetně sklářské výroby), a to i přes to, že obě nedestruktivní metody nemohou poskytnout spolehlivější data potřebná $\mathrm{k}$ přesné interpretaci výrobních areálů. Velkým př́ínosem publikace (kapitoly 1.4 .9 a 1.7) je vyhodnocení sklářského odpadu: klasifikace, prostorová analýza a v neposlední řadě vyhodnocení v celoevropském kontextu (kapitola 3.2.4). Soubor dokládající sklářskou výrobu na lokalitě představuje 451 fragmentů, kde jsou zastoupeny polotovary lokálně vyráběných perel, skleněná vlákna a kapky a v neposlední řadě i surové sklo. U některých korálků byla prokázána lokální výroba - jde o typy 117, 119, 122 a 155. Sklářský odpad se jeví nejen jako důkaz činnosti sekundárních sklářských dílen, $\mathrm{v}$ řadě prŕípadů pomáhá rekonstruovat i původní výrobní postupy. ${ }^{5}$

Autorkou publikace byl pečlivě zpracován i soubor hotových skleněných výrobků z Němčic, které byly detailně zdokumentovány a byly podrobeny typologicko-chronologické analýze. Soubor skleněných předmětů zahrnuje skleněné perly (730 kusů), náramky (534), tzv. Ringperly (14), prsteny (19) a rozdělovače (9), přičemž soubor skleněných náramků je považován za druhý největší v Evropě (po souboru 616 fragmentů náramků z Manchingu).

V kapitole 1.4.4 autorka provedla detailní rozbor skleněných náramků z Němčic. I zde odvedla více než pečlivé tř́idění a katalogizaci každého nálezu. Chronologický rozbor náramků byl proveden na základě předešlých studií, ${ }^{6} \mathrm{v}$ potaz byl brán jak konkrétní typ náramku, tak i barva skla, která je rovněž chronologickým identifikátorem. Kapitola je doplněna o mapové podklady, kde je sledováno rozšíření konkrétních typů v kontextu středního Podunají. Nálezy z Němčic nevykazují výrazně regionální specifika a převážnou část nálezového souboru je možné zařadit do rámce LT C1 - LT C2. Celému souboru dominuje skupina č. 13 (111 kusů), následuje skupina č. 8ab (107) a skupina č. 3a (57). Je zajímavé, že z Němčic pochází největší soubor náramků skupiny č. 15 , a to i přes to, že je zastoupen pouze 4 jedinci.

Soubor skleněných korálků z doby laténské čítá 730 jedinců. Autorka zároveň vyčlenila i starší typy korálků s očky (typy 519, 533 a 554), melounovité korálky (typ 307) a tmavě modré s bílou vlnovkou (typ 708), které se datují do pozdní doby halštatské, ovšem výjimečně se nacházejí i v mladších kontextech. Př́ínosným počinem autorky je pečlivé roztřídění skleněných korálků podle typologických skupin. ${ }^{7}$ Ze souboru skla z Němčic bylo navíc vyčleněno několik nových typů:
168-172, 416-421, 533-555, 719-724 a 904. Bohužel, nová typologická řada nebyla začleněna do klasifikačních tabulek podle starší studie autorky, ${ }^{8}$ což poměrně znesnadňuje orientaci v tabulkové príloze. Souboru dominuje jednoduchý typ 117 (515 jedinců), výrazný podíl má i typ 155 (112 jedinců). U nich byla na základě sklářského odpadu identifikována lokální výroba.

Soubor skla z oppida Staré Hradisko byl podroben stejně detailnímu vyhodnocení. Nevýhodou je ovšem skutečnost, že výrazná část skla (407 artefaktů z celkových 607) pochází ze starších výzkumů, takže je bez identifikovatelného archeologického kontextu. Vzhledem k této skutečnosti má prostorová distribuce skleněných artefaktů nízkou výpovědní hodnotu. Z důvodu nízkého počtu výrobního odpadu je identifikace hypotetických sklářských dílen v dnešní době nemožná. Soubor skla ze Starého Hradiska je z kvantitativního hlediska oproti Němčicím výrazně skromnější. Je ale nutné podotknout, že kupř́íkladu nižší počet skleněných perel $(90$ fragmentů) je podmíněn spíše metodou výzkumu nežli primárním nedostatkem těchto ozdob. Skleněné perly byly typologicky roztrríděny podle stejného klíče jako soubor z Němčic. Celému souboru dominuje jednoduchý typ 117 kobaltové barvy (33 jedinců), zbylé typy jsou zastoupeny jen pár kusy. V souboru ze Starého Hradiska bylo vyčleněno několik nově identifikovaných typů skleněných perel (422-424, $556,722,725,809$ a 810$)$. Typově perly odpovídají chronologickému rámci LT C2-D. Vhodné je zároveň zmínit vysoký počet Ringperel s počtem 202. Zde převládá skupina č. 23 - perly s jednoduchým vlnovkovým ornamentem. I zde převládá kobaltově modrá; zelené, fialové a sytě oranžové barvy jsou zastoupeny méně. Skupina náramků obsahuje 105 jedinců, kde dominuje jednoduchý nezdobený typ 3a převážně kobaltově modré barvy. Druhým nejpočetnějším je typ $13 \mathrm{a}$ (14 jedinců).

Za výjimečný je považován soubor fragmentů helénistických skleněných nádob: 13 fragmentů nádob typu millefiori a 9 fragmentů monochromních nádob vyráběných ve formě. Zmíněné nádoby se dají s jistotou považovat za doklad importu ze Středomoří, rámcově datovaného do 2. až 1. století př. n. 1. Mimo ,antický svět“ je známo pouze 10 souborů helénistického skla typu millefiori, v tomto kontextu je nález ze Starého Hradiska významným dokladem intenzivních obchodních vztahů podél Jantarové stezky.

Typologický a prostorový rozbor nálezů z obou lokalit je doplněn kapitolou zaměřenou na otázku chemického složení skel z doby laténské. Fragmenty helénistických skel typu millefiori ze Starého Hradiska byly v minulosti již podrobeny chemické analýze a následně i publikovány v samostatné odborné studii. ${ }^{9}$ Soubor skel z lokality Němčice byl také podroben detailnímu průzkumu pomocí metody NAA a SEMEDS. ${ }^{10}$ Výsledky zmíněných analýz (stejně jako měření skel z oppida Stradonice) jsou veřejně př́istupné v online databázi

\footnotetext{
${ }^{4}$ Roman KŘIVÁNEK, Shrnutí výsledků dosavadních geofyzikálních měření v areálu laténského sídliště v Němčicích nad Hanou, in: J. ČIŽMÁŘOVÁ N. VENCLOVÁ - G. BŘEZINOVÁ (eds.), Moravské křižovatky, s. 785-799.

${ }^{5}$ Např. John SHEPHERD - Angela WARDLE, The Glass Workers of Roman London, London 2009.

${ }^{6}$ R. GEBHARD, Der Glasschmuck aus dem Oppidum von Manching, Stuttgart 1989; N. VENCLOVÁ, Prehistoric glass in Bohemia, Praha 1990; M. KARWOWSKI, Latène zeitlicher Glasringschmuck aus Ostösterreich, Vien 2004; Gertrúda BŘEZINOVÁ - Natálie VENCLOVÁ - Jaroslav FRÁNA - Marek FIKRLE, Early blue glass bracelets in the Middle Danube region, Slovenská archeológia, 2013, roč. 61, s. $107-142$.

${ }^{7}$ N. VENCLOVÁ, Prehistoric glass in Bohemia, Praha 1990.

${ }^{8} \mathrm{Viz}$ pozn. 7.
} 
ARUP AV ČR VITREA. V kapitole 3.2.3 autorka podává shrnující zprávu o stavu bádaní v rámci studia chemického složení laténského skla $\mathrm{v}$ širším celoevropském kontextu. Přehled obsahuje zásadní práce zabývající se touto problematikou a může sloužit jako základní informační zdroj pro studium a poznání skla v době laténské. Zde jsou shrnuta základní fakta týkající se chemického složení laténského skla a jeho proměn $v$ průběhu chronologických stupňů. Zajímavou otázkou je i zdroj/zdroje surového skla a jeho transport na území střední Evropy. Zde se můžeme bezesporu těšit na další práce autorky na toto téma (konkrétně analýzy surového skla a monochromních nádob ze Starého Hradiska).

Publikace Němčice and Staré Hradisko. Iron Age glass and glass-working in Central Europe je prríkladem kvalitního zpracování velkých souborů skleněných nálezů. Autorka se sobě vlastní pečlivostí vytvořila komplexní katalog, který je doplněn textovou a obrazovou prílohou. Nechybí zde ani základní typologicko-chronologické roztřídění jednotlivých nálezů s následným vyhodnocením celého souboru. Jedinou výtkou je náročnější orientace v obrazové příloze a nedoplněné typologické tabulky skleněných korálků o nové typy. Bezpochyby velkým přínosem je i zasazení výsledků do širšího celoevropského kontextu, což je v dnešní době bezpochyby podmínkou pro kvalitní zpracování zkoumaného materiálu. Vyzdvihla bych i snahu interpretovat existenci sklářských dílen, místní výrobky, výrobní postupy a zdroj suroviny, a to jak na samotných lokalitách, tak i v širším středodunajském prostoru. Spolu se starší publikací11 je i tato práce zásadním zdrojem informací pro studium otázek spojených se sklem v době laténské.

\footnotetext{
${ }^{9}$ Natálie VENCLOVÁ - Václav HULÍNSKÝ - Šárka JONÁŠOVÁ - Jaroslav FRÁNA - Marek FIKRLE - Tomáš VACULOVIČ, Hellenistic mosaic glass vessels in Bohemia and Moravia, Archeologické rozhledy, 2015, roč. 67, s. 213-238.

${ }^{10}$ Natálie VENCLOVÁ - Václav HULÍNSKÝ - Jaroslav FRÁNA - Marek FIKRLE, Němčice a zpracování skla v laténské Evropě. Archeologické rozhledy, 2009 , roč. 61 , s. 383-426.

${ }^{11}$ N. VENCLOVÁ, Prehistoric glass in Bohemia, Praha 1990.
} 